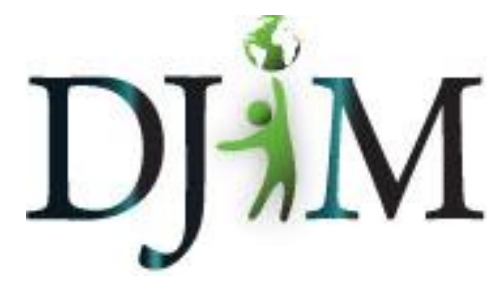

Volume 7 - Spring 2011 djim.management.dal.ca

\title{
No Magic Solution: An examination of the arguments in favour of contracting out government services
}

\section{Joey O'Brien}

\begin{abstract}
This paper examines the arguments commonly used to support contracting out service delivery to the private sector and attempts to demonstrate that these arguments overestimate the benefits of contracting out. First, the economic savings attributed to contracting out service delivery are considered and shown to omit important supplementary costs associated with the contracting process. Next, empirical evidence is used to test the common argument that private sector service delivery is always superior to that of the public sector. Finally, the assertion that contracting out service delivery will lead to innovative solutions to government's problems is explored. This paper attempts to demonstrate that internal reforms of government structures should be considered as a strong alternative option to contracting out.
\end{abstract}

\begin{abstract}
About the Author(s): The author is a first year Masters of Public Administration Student at Dalhousie's School of Public Administration. He graduated from the University of Toronto in 2008 with an Honours Bachelors of Arts degree in political science and history. His research interests include how Alternative Service Delivery has been organized within Canada and how new technologies can be used to improve government operations. This paper was written for a course which examined the design of government structures and was accompanied by an in class presentation.
\end{abstract}




\section{Introduction}

"Government is the problem:" this popular phrase, famously expressed by U.S. President Reagan in 1981, characterizes how many individuals view government. Bureaucrats are often seen as unmotivated and uncreative. Decisions that seem obvious are discussed for ages, and services which should be delivered without difficulty are unnecessarily delayed. At times, government can appear unconcerned with the costs of their actions and act as if the taxpayer's purse is bottomless. A popular "solution" to the "problem of government," is to reform government operations and run government as if it were a business (Gangl, 2007). Private companies are not only able to manage costs effectively, but they can create innovative solutions while still delivering high quality service. However, an institution such as government is not easy to restructure. Any potential reformers would need to fight budgetary restraints, institutional inertia, and powerful public sector unions categorically resistant to change. To circumvent this long and costly process, while still achieving a more businesslike government, certain services can be bundled together and contracted out to the most competitive bidder. In this way government can save money, improve service quality, and develop innovative solutions without fighting with unions at every step of the reformation process. Although this is an appealing prospect, like most simple solutions, it fails to consider many important factors. This paper will address the alleged economic, service, and innovative benefits of contracting out government services and demonstrate that they are significantly overestimated. It will become apparent that, in most circumstances, contracting out is a poor alternative to making substantial internal reforms.

\section{An Examination of the Arguments in Favour of Contracting Out Government Services}

A common justification for contracting out any particular government service is that it will save the government money. This is far from an unsubstantiated claim; numerous academic studies have demonstrated that significant cost savings can be generated by contracting out service delivery. Although the exact amount of cost savings calculated varies to a significant degree, with some studies indicating an average cost savings of $20 \%$ and others a range between 10 $30 \%$, there is a strong consensus that in terms of economic benefits alone contracting out makes sense (Hodge, 1998). Such significant savings present a major motivation for any government manager tasked with cutting their department's expenses. By contracting out certain secondary services in their departments, such as cleaning services, they can save money and prevent job losses among their more essential staff. However, these raw numbers are not indicative of the true cost savings that can be attained by contracting out, as they fail to consider relevant auxiliary costs, financial risks associated with contracting and most importantly they mistake savings associated with competition with savings generated by private sector efficiency. 
One of the most comprehensive international analyses examining the cost savings of contracting out was performed by Hodge in the 1990s. Although Hodge attempted to be more comprehensive in his analysis than others, even his extensive study failed to consider a large amount of supplementary costs associated with contracting out. When a government makes a contract for service delivery with a private firm they have already spent a significant amount of resources developing the details for that contract. Even a relatively straightforward job, such as the operation of a service call centre, would require a detailed contract that incorporates: dispute resolution mechanisms; milestone payments; and, material on quality inspection arrangements. For complicated services, such as an Information Technology (IT) contracts, issues such as intellectual property rights and communication routes to the media need to be written out in detail (Office of Government Commerce, 2010b). The costs associated with developing these detailed arrangements are not assessed when determining the savings generated from contracting out the service. Although such costs are difficult to measure, studies have demonstrated that they routinely amount to approximately $2-3 \%$ of the cost of the contract (Office of Government Commerce, 2010b). However, even if these development and monitoring costs are taken into account, the true savings associated with contracting out are nowhere near being accurately determined.

In The United Kingdom the Office of Government Commerce (OGC) warns government managers that the abilities required to develop and monitor a contract may not exist within the civil service, "[t]he skills and experience required to manage the relationship [with a contractor] may be different from those required to manage service delivery"(Office of Government Commerce, 2010b, p.2). The OGC recommends that where this is the case, additional staff training should occur, to re-educate the civil service on how to manage contracts. However, the OGC warns that in some instances even new training will not be enough to manage a truly complex contract and a special professional contract manager may need to be hired (Office of Government Commerce, 2010b). The costs associated with this re-education and this potential new hire are also not included when assessing the economic benefits of contracting out a service.

Finally, when a service is contracted out it usually results in lost jobs. If these individuals now go on unemployment insurance the costs associated with this are not considered. In 1995, the British Centre for Public Service estimated that, as a result of contracting out services, the government saved £16 million, but since unemployment increased by £24 million contracting out was a net loss to the government (Hodge, 1998). Although this think tank is closely related to the labour movement and thus likely to have a negative view of contracting out, it is not inaccurate to assume some increase in unemployment would be associated with contracting out. This cost needs to be considered if the true financial benefits of contracting out are to be accurately determined.

In addition to disregarding significant supplementary costs, when the economic benefits of a contract are determined, the financial risks associated with contracting out that service are not 
commonly addressed. One of the most significant risks is that a particular government department will become too dependent on a single supplier. The end result of such an arrangement is that over the long run there would be a decrease in competition amongst industry suppliers leading to an increase in costs. This is a real threat to contracting out, especially where the service in question is complex in nature. The Auditor General of Canada has warned that IT contracts face this problem as the systems used by the government are so old and complex that, "the only people who may know how these system's work are the[original] contractors"(The Professional Institute of the Public Services of Canada, 2010, Para. 4). When a government becomes dependent on one particular supplier they are unable to ensure that they are receiving the best value for their money and the economic benefits associated with contracting out are called into question. In 1997 the Ontario Government signed a \$284 million deal with Anderson Consulting to develop a computer system to help manage the government's welfare program. Not only did Anderson deliver the system late and over budget, but the system that was created turned out to be inefficient and prone to breakdowns (Brennan \& Benzie, 2004). Yet, in 2002 when the contract for maintaining this system was put to tender, unsurprisingly Anderson won the contract (Brennan \& Benzie, 2004). They were the only company that could manage the ineffective system that they had created. The Ontario government had become beholden to Anderson. In a situation such as this, the competitive process of contracting had been significantly disrupted and the cost savings that contracting is able to deliver could no longer be said to exist. The risk of dependency needs to be considered when a government is making the decision whether to contract out service delivery or not. If the risks of dependency are high then the cost savings of contracting out over the long run are likely to be small.

Finally, when the benefits of contracting out are determined, they include both the benefits of competition and the benefits associated with private business practices. Although competition is part of the contracting out process, the cost savings associated with it can be attained by government departments so long as they are allowed to compete with outside providers. In other words, the costs savings associated with competition are not an accurate portrayal of how contracting out services can save money, but merely show how competition reduces costs. The U.S. General Accounting Office has demonstrated that when private sector companies are able to compete against government departments, private sector bid winners have 39\% lower costs than government losers. Conversely, private sector bid losers have costs 33\% higher than winning government departments (Hodge, 1998). To say that contracting out saved $39 \%$ or retaining government control saved $33 \%$ is inaccurate. These savings were generated by competition and are not indicative of higher or lower private sector productivity. In fact, evidence demonstrates that direct competition between the private and public sector is not even necessary to obtain costs savings. The mere threat of competition with the private sector is enough motivation for civil servants to increase their efficiency and cut costs. In the United Kingdom, when services in one hospital were contracted out to the private sector, the nearby hospitals reduced their costs by $7 \%$ (Hodge, 1998). Thus, the ability 
of the public sector to compete and attain costs savings similar to the private sector demonstrates that internal reforms of the public sector, while initially difficult, can result in similar cost savings as contracting out. Thus control and accountability do not need to be sacrificed in order for better efficiency to be attained.

In addition to economic benefits, supporters of contracting-out services claim that private sector providers can deliver higher quality service then government departments. According to this way of thinking, the private sector's treatment of individuals as customers and use of performance incentives would increase both the speed and quality of the service delivered. In time, the unmotivated bureaucrat will become a helpful customer service agent, paid on the basis of how many citizens that they serve. In British Columbia, this theory was put into practise in 2003 when the provincial government signed a ten year $\$ 1.45$ billion agreement with Accenture Inc. to provide call centre support to B.C. Hydro. Evidence suggests that rather than increasing service quality this arrangement caused the former civil servants, acquired in the deal, to sacrifice quality of support for quantity of calls received. Workers reported that the company unilaterally increased their production quotas by $20-30 \%$ and as a result it is no longer possible for them to 'go the extra mile' when assisting a customer but instead they are forced to provide only the most basic of services (Gurstein \& Murry, 2007). One worker describes the transition as replacing the interests of citizens with that of shareholders, "Their [Accenture] attitude is everything should be for the company. This company is all about giving money to its shareholders, which is just totally foreign to us. Our shareholders are the citizens of the province."(Gurstein \& Murry, 2007, p.27). Thus quality is sacrificed for speed, and although this sacrifice may be deemed acceptable, it is incorrect to state that in comparison to the civil servants, who used to provide the call centre support, that the new arrangement is better. There is no reason why internal reforms could not also result in the same trade-off between quality and quantity.

Another indicator that service quality has decreased is that the organization has lost a considerable amount of institutional memory. One of the first methods that Accenture used to cut costs was to eliminate the mandatory ten days a year that employees received for new training (Gurstein \& Murry, 2007). Without new training, it is difficult to see how service quality can increase. Even more significant, since acquiring the former civil servants an astounding number have left Accenture's employment. Approximately $26.4 \%$ of the staff who worked in supporting roles at B.C. Hydro left their jobs when the contract with Accenture was first being negotiated (Gurstein \& Murry, 2007). Of the 1,540 former civil servants that remained, many have subsequently left Accenture's employment. In 2004, 14.4\% resigned or retired and in 2005 an amazing $23.7 \%$ left the organization (Gurstein \& Murry, 2007). This mass exodus means a reduction in the institution memory of the organization thus decreasing its ability to deal with complicated issues.

Finally, while a citizen receiving a service from the government has clear channels to complain about the level of service that they receive, a customer receiving a service from a private 
organization is severely limited in their options. Those wishing to reform government claim that government can be slow to respond to a citizen's complaint; however, this slowness is the result of the complaint working its way up, and then back down the hierarchical chain of command (Fountain, 2002). The eventual response from government may take months and may be of little assistance, but the government is obligated to address the citizens' concern. In contrast, the only responsibility that a private contractor has is to fulfill the terms of their contract. If the contractor is meeting all obligations under the contract there is nothing that a citizen or the government operating on behalf of a citizen can do to force the contractor to change their behaviour (Mulgan, 1997). Although, this lack of responsiveness is primarily a matter of accountability, it also has the potential to impact levels of service quality, since without responding to citizens' feedback, service quality is unlikely to improve.

The competition in the private sector not only contributes to cost reduction and service improvements it also results in constant innovation. Supporters of contracting out say that the government can tap into this innovation by issuing tenders that are outcome rather than input specific. In other words, a contract can ask for only the end result and not specify how these results should be achieved. According to the OGC this method of contracting is, "equivalent to specifying the problem and inviting solutions" (Office of Government Commerce, 2004a, p. 9). Such a technique is a direct contrast to how public servants traditionally view a problem. To public servants it is the inputs not the end result that are most important. A public servant is trained to concentrate on issues of fairness and equality when approaching a problem and follow all the established protocols and procedural rules in formulating a solution. As a result, many argue that the innovation characteristic of private sector cannot be achieved within government, no matter how extensively the public sector is reformed. Those opposed to contracting out services, such as Professional Institute of Public Servants of Canada, argue that sacrificing these inputs considerations in favour of innovative outcomes is detrimental to society as a whole. They say contracting out service delivery is simply an attempt to circumvent important legislative requirements for government services such as: the Official Languages Act, Employment Equity considerations, and the complex hiring practises of the Public Service Commission (The Professional Institute of the Public Services of Canada, 2010). If society really values these services, as they claim, contracting out services needs to be severely curtailed.

While these arguments are important to contemplate, they are beyond the scope of this paper. Instead the assertion that output based tendering leads to innovative solutions needs to be examined in greater detail as it is not an assertion that is universally agreed upon. In fact, it is unclear whether governments are able to effectively create or utilize innovative solutions developed by private sector contractors. The risk-adverse public sector mentality does not disappear when it is presented with an innovative solution from the private sector. Instead of adopting the solution immediately, what often occurs is that a pilot program is created to determine if the innovative solution is an appropriate option for the government to adopt. 
However, even if the pilot project is successful the innovative solution is regularly not carried through to the government as a whole. The public sector's tendency to opt for the low-risk, lowcost resolution takes over and traditional solutions are adhered to (Office of Government Commerce, 2004a). Thus, public servants risk adverse nature may prevent them from being innovative themselves, but is also restricts their ability to adopt the innovative solutions developed by others.

Innovation also suffers in public sector contracts because of the problem of "creeping regulation". A project may start off with the government agency only concentrating on the desired outcome, but overtime the contract will be re-negotiated and 'perfected' with many stipulations are added to the agreement. These stipulations limit both the contractor's ability to innovate as well as their motivation to develop innovative solutions. For example the OGC recommends that when negotiating a contract for a particularly complex project, efforts should be made to prevent excess profits (Office of Government Commerce, 2010a). That is, a cap should be placed on the amount of money a contractor can make on a particular project regardless of how innovative a solution they develop. Such regulation will likely limit the motivation of contractors to become innovative and thus prevent government from capturing new solutions to problems.

\section{Conclusion}

This paper has concentrated on challenging the alleged strengths of contracting out services, not in an attempt to demonstrate that contracting out never works, but to address the fact that contracting out is not a "magic" solution to all of government's problems. Contracting cannot simultaneously correct government inefficiency, remedy government's mediocre service standards and fix government's out-dated way of thinking. Instead it is one of many tools at government's disposal, there are benefits to using such a tool, but these benefits are limited in their scope. As government faces new financial pressure it is important for policy makers to have a realistic understanding of the options available to them and not be deceived into believing simple solutions, such as contracting out, can solve the complex problems confronting government. 


\section{References}

Boston, J. (1994). Purchasing policy advice: the limits to contracting out. Governance, 7(1):130.

Boston, J. (2000). Organizing for Service Delivery: Criteria and Opportunities. In G. Guy Peters \& Donald J. Savoie (Eds.), Governance in the Twenty-first Century: Revitalizing the Public Service (pp. 281-331). Montreal: McGill-Queen's University Press.

Brennan, R \& Benzie, R. (2004). How costly computer sparked a 'nightmare`. The Toronto Star. Retrieved from http://webspace.oise.utoronto.ca/ sawchukp/2THEST 1.HTM

Office of Government Commerce. (2004a). Capturing Innovation. Best Practices Guidelines. Retrieved from http://www.ogc.gov.uk/documents/capturing_innovation.pdf

Office of Government Commerce (2010a).Contract Management in Long Term or Complex Projects. . Best Practices Guidelines. Retrieved from http://www.ogc.gov.uk/ documents/Contract_Management_in_Complex_Procurement(1).pdf

Office of Government Commerce. (2010b). Contract Management Checklist. Best Practices Guidelines. Retrieved from http://library.concordia.ca/help/howto/apa.php

Fountain, J. (2002). Paradoxes of Public Sector Customer Service. Goverance, 14(1), pp.5573.

Gangl, A. (2007). Examining Citizen's Belief That Government Should be Run Like Business. Public Opinion Quarterly, 71(4), pp.661-670.

Office of Government Commerce. (2004b). Guidance to the risks of over-dependency on a supplier. Best Practices Guidelines. Retrieved from http://www.ogc.gov.uk/documents/Guidance_to_reduce_the_risks_of_overdependency_on_a_supplier.pdf

Gurstein, P \& Murry, S. (2007). From Public Servants to Corporate Employees: The BC Government`s Alternative Service Delivery Plan in Practice. Canadian Centre for Policy Alternatives. Retrieved from http://www.policyalternatives.ca/sites/default/files/uploads/publications/BC_Office_Pubs/ bc_2007/bc_FromPublicServants.pdf.

Hodge, G. (1998, February). Contracting public sector services: a meta-analytical perspective of the international evidence. Paper presented at the Conference on Public Policy and 
Private Management, the Centre for Public Policy, Melbourne University. Retrieved from http://web.ebscohost.com.ezproxy.library.dal.ca/ehost/search?vid=1\&hid=105\&sid=ecbc 817d-cc14-4852-8c75-6a330f35f803\%40sessionmgr111

Martin, J. (1995). Contracting and accountability. In J. Boston (Ed.), The state under contract. Wellington; Bridget Williams Books.

Mulgan, R. (1997). Contracting out and accountability. Australian Journal of Public Administration, 56(4), pp.106-116.

Panet, P. \& Trebilock, M. (1998) Contracting out social services. Canadian Public Administration, 41(1), pp. 21-50.

The Professional Institute of the Public Service of Canada. (2010). Contracting Out... the real picture! Communications Magazine. Retrieved from. http://www.publicscience.ca/portal/page/portal/website/news/magazine/spring2010/7

Reagan, R.(1981). Inaugural Address. Washington D.C. Retrieved from http://www.reagan.utexas.edu/archives/speeches/1981/12081a.htm 